\title{
Determination of Adsorption Isotherm model best fit for methanol leaf extract of Securinega virosa as corrosion inhibitor for corrosion of mild steel in $\mathrm{HCl}$
}

\author{
S. O. Adejo*a, M. M. Ekwenchi ${ }^{\text {b }}$, J. A. Gbertyo ${ }^{a}$, T. Menenge ${ }^{a}$, J. O. Ogbodo ${ }^{c}$ \\ ${ }^{a}$ Department of Chemistry, Benue State University, Makurdi-Nigeria \\ ${ }^{b}$ Department of Pure and Industrial Chemistry, University of Jos-Nigeria \\ ${ }^{c}$ Benue State Polytechnic, Ugbokolo, Benue State, Nigeria \\ *Corresponding Author: sadejo@bsum.edu.ng/soadejo@gmail.com \\ $+2348054557652$
}

\begin{abstract}
The adsorption isotherm model best fit of the methanol leaf extract of Securinega virosa as corrosion inhibitor for the corrosion of mild steel in $2 \mathrm{M} \mathrm{HCl}$ medium was determined with the assistance of the Adejo-Ekwenchi adsorption isotherm. The corrosion inhibition study was carried out using the weight loss method at the temperature range of $301 \mathrm{~K}$ to $313 \mathrm{~K}$. The inhibition efficiency, \%IE, of the extract was found to increase with increase in both concentration and temperature. On the account of, $\mathrm{R}^{2}$ this adsorption process well fitted into Langmuir, Freundlich, Temkin isotherm, FloryHuggins and Adejo-Ekwenchi models. However, through the parameter b of the Adejo-Ekwenchi isotherm, which clearly shows the adsorption process to be chemisorption, the best isotherm fit for the extract has been resolved to be the Langmuir isotherm and Temkin isotherm models.
\end{abstract}

\section{Keywords}

Adsorption isotherm; Mild steel; Securinega virosa; Adejo-Ekwenchi isotherm; Chemisorption

\section{Council for Innovative Research}

Peer Review Research Publishing System

Journal: Journal of Advances in Chemistry

Vol. 10, No. 5

editorjaconline@gmail.com

www.cirjac.com 


\section{INTRODUCTION}

Adsorption, the accumulation onto the surface of a solid or a liquid (adsorbent) by gas or liquid molecules (adsorbate), is a process which is present in many physical, biological and chemical systems [1, 2]. In fact, adsorption process has been recognised as the most efficient, promising and widely used fundamental approach in wastewater treatment [3] and corrosion inhibitors act through it in the protection of metals against corrosion. Usually, the process of adsorption is empirically described in terms of amount adsorbed as a function of pressure (or concentration) and temperature [4].

The relationship between the amount of the adsorbed substance to its bulk concentration in the adsorption process at a particular temperature and $\mathrm{pH}$ is known as adsorption isotherm [5]. Adsorption isotherm is usually described by an isotherm equation whose parameters express the surface properties and affinity of the adsorbate and from which the mechanism of the adsorption process can also be deduced [6]. The establishment of adsorption equilibrium correlation is indispensible for the prediction of reliable adsorption parameters [3]. For example, in corrosion inhibition process the mechanism of inhibition can better be understood through the use of isotherms [7, 8].

The fitness of adsorption data into an isotherm has largely been determined through the value of the regress coefficient, $R^{2}$, while the Gibb's free energy, $\Delta G_{\text {ads }}$, value has, usually, been employed to ascertain whether the process is physisorption or chemisorption. However, most isotherm equations are non-linear, and therefore their transformation to linear forms implicitly alters their error structure and may also violate the error variance and normality assumptions of standard least squares [4]. Also, many authors have argued that the value of $\Delta \mathrm{G}_{\text {ads }}$ below $-20 \mathrm{~kJ} / \mathrm{mol}$ is an indication of physisorption, while value above $-40 \mathrm{~kJ} / \mathrm{mol}$ has been ascribed to chemisorption. But, Popova and Co-workers [9] have put forward that the use of $\Delta G_{\text {ads }}$ criterion only will be difficult to make such distinction, as there is the possibility of existence of coulombic interaction between charged species, especially in the cases where charged species are adsorbed, which can lead to increment in the $\Delta G_{\text {ads }}$ value, even if no new chemical bonds are formed. Evidently, there exist ambiguity in the use $R^{2}$ and $\Delta G_{\text {ads }}$ as sole criteria for the determination of isotherm best fit of adsorption process. However, the Adejo-Ekwenchi isotherm, unambiguously, facilitates the clear resolution of adsorption isotherm best fit as demonstration therein $[10,11]$.

In this research the adsorption isotherm best fit for methanolic leaf extract of Securinega virosa as a green corrosion inhibitor of corrosion of mild steel in $\mathrm{HCl}$ was determined, largely, through the use of a new proposed twoparameter Adejo-Ekwenchi isotherm.

\section{EXPERIMENTAL}

\subsection{Materials}

Securinega virosa leaves were collected within the premises of Benue State University, Makurdi-Nigeria, rinsed with distilled water, air dried for 40 days under shade and then size-reduced with a pestle and mortal in the Chemistry Department of the same University. $20 \mathrm{~g}$ of the powdered leaves was soaked in $200 \mathrm{~mL}$ of $98 \% \mathrm{methanol}$ (BDH Chemicals Ltd, Pool, England) in a $500 \mathrm{~mL}$ volumetric flask for 48 hours, with occasional shaking. The extract obtained therefrom was filtered using glass wool and methanol was slowly evaporated from the filtrate at $321 \mathrm{~K}$ (to avoid any possible structural changes to the components of the residue) using thermostated water bath (Clifton: Nickel-Electro Ltd, England) [12]. The residue was preserved in a desiccator, from which stock solutions of $0.1,0.2,0.3,0.4$ and $0.5 \mathrm{~g} / \mathrm{dm}^{3}$ concentrations were prepared in $2 \mathrm{M} \mathrm{HCl}$ ( $\mathrm{M} \& \mathrm{~B}$, Bagenmam, England).

Coupons (2 $\mathrm{cm} \times 2 \mathrm{~cm} \times 0.13 \mathrm{~cm}$ dimension each) were prepared as reported earlier [13] from a sample of mild steel of composition (\%W): $\mathrm{Fe}(98.84), \mathrm{Mn}(0.56), \mathrm{P}(0.04), \mathrm{C}(0.27), \mathrm{Si}(0.25)$ and $\mathrm{S}(0.04)$.

\subsection{Methods}

The coupons, degreased in acetone (99\% BDH Chemicals Ltd Pool, England), were carefully weighed using ae Adam AFP $(\mathrm{d} \pm 0.0001 \mathrm{~g})$ electronic weighing balance and immersed in $50 \mathrm{~mL}$ of the acid solutions in $100 \mathrm{~mL}$ beaker, without and with various concentrations of the inhibitor at the temperature range of $301 \mathrm{~K}$ to $313 \mathrm{~K}$ in the water bath for 8 hours. At the retrieval of each coupon, the corrosion reaction was terminated by dipping the coupons into saturated solution of ammonium acetate (97\% Labtech Chemicals Limited) as outlined by Orubite-Okorosaye and Oforka [14] and then stored in the desiccator until ambient temperature was attained and re-weighed. The \%IE and surface coverage $(\theta)$ were calculated through equations (1) and (2), respectively [15-18].

$$
\begin{aligned}
\text { IE } \% & =1-\frac{w_{\text {inh }}}{w_{\text {uninh }}} \times 100 \\
\theta & =\left(1-\frac{w_{\text {inh }}}{w_{\text {uninh }}}\right)
\end{aligned}
$$

where $W_{\text {uninh }}$ and $W_{\text {inh }}$ are weight losses in absence and present of inhibitor, respectively. 


\section{RESULTS AND DISCUSSION}

Table 1 shows the variation of \%IE of the plant extract as corrosion inhibitor for the corrosion of mild steel sample in $2 \mathrm{M}$ $\mathrm{HCl}$ with the extract concentration and temperature. It is obvious from the Table that the \%IE increased with increase in both the concentration of the extract and rise in temperature. The increase in the \% $\mathrm{IE}$ with rise in temperature is suggestive of chemisorption [19].

Table 1. Variation of Inhibition Efficiency (\%IE) with Concentration and Temperature of Leaf Extract of Securinega virosa

\begin{tabular}{ccccc}
\hline Conc. $(\mathrm{g} / \mathrm{dm} 3)$ & \multicolumn{4}{c}{$\% \mathrm{IE}$} \\
& $301 \mathrm{~K}$ & $305 \mathrm{~K}$ & $309 \mathrm{~K}$ & $313 \mathrm{~K}$ \\
\hline 0.1 & 25.61 & 36.29 & 37.18 & 44.32 \\
0.2 & 46.68 & 48.72 & 48.95 & 57.16 \\
0.3 & 58.69 & 60.12 & 65.37 & 66.88 \\
0.4 & 66.19 & 69.59 & 73.15 & 74.91 \\
0.5 & 69.03 & 73.67 & 74.25 & 77.32 \\
\hline
\end{tabular}

The inhibitive action of organic compounds has been ascribed to the formation of surface layers and films on the metal surface, thereby reducing the accessibility of the corrodant to the metal surface. And adsorption isotherms have been used to characterise this inhibitive action. The most frequently used of such isotherms are the Langmuir, Freundlich, Frumkin, Temkin, Flory-Huggins, Bockris-Swinkels and the El-Awady thermodynamic-kinetic model [20, 21] and the recently proposed Adejo-Ekwenchi isotherm $[10,11]$. Linearised forms of these isotherm equations are given equations (3) to (10) below.

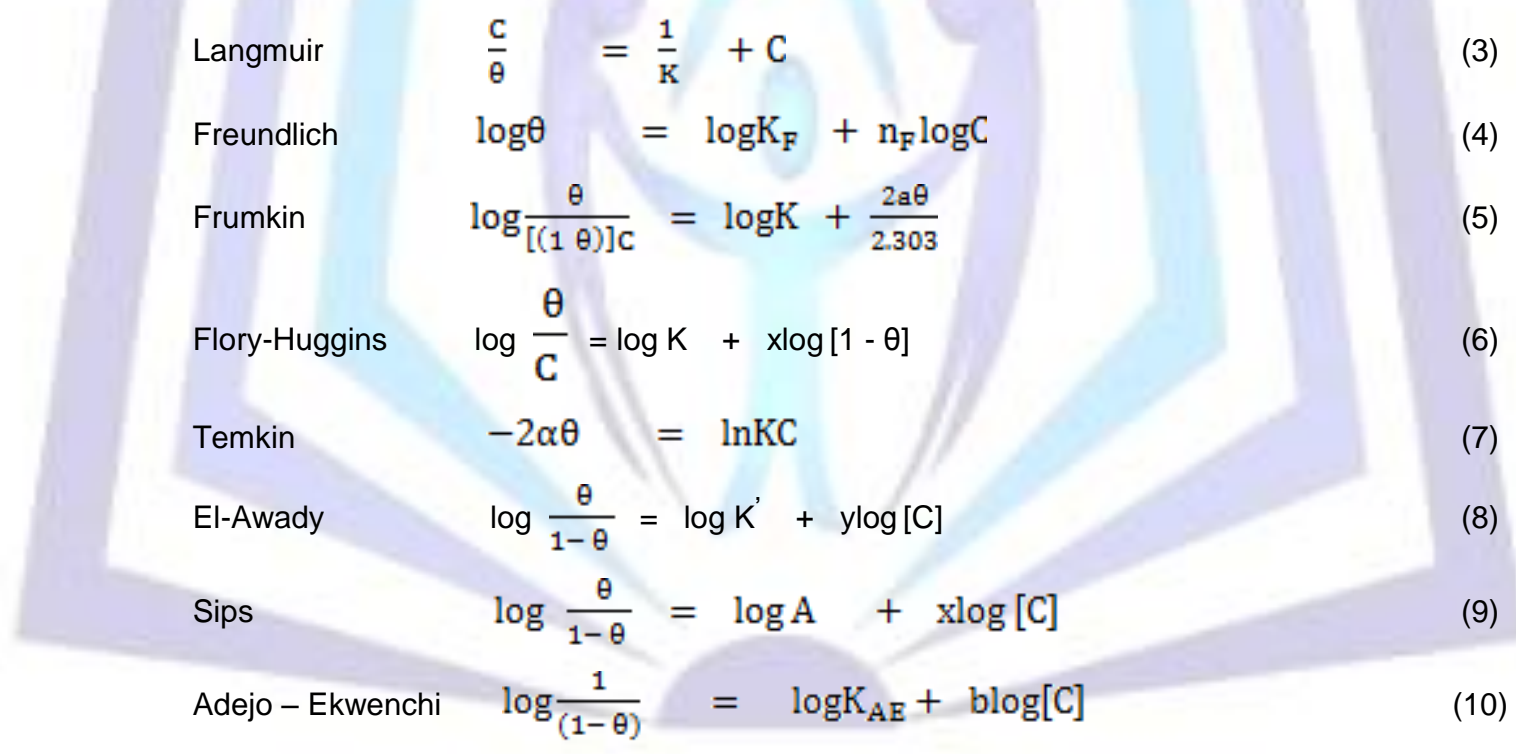

Many authors have employed the value of regression coefficient, $R^{2}$, to determine the fitness of adsorption process data to an adsorption isotherm. Taking this into cognisance, therefore, the data for this plant extract can be said to fit well into the Langmuir, Freundlich, Temkin, Flory-Huggins and Adejo-Ekwenchi isotherms (Table 2). The values of equilibrium constant, $\mathrm{K}_{\mathrm{ads}}$, of all the isotherms (Table 2) are all positive, implicitly, indicative of favourable adsorption [7]. The Sshaped curve of the plot of \% IE against the logarithm of concentration as depicted by Figure 1 (at $313 \mathrm{~K}$ ) further attests to the fact that an adsorbed layer was actually formed on the metal surface by the extract $[7,22]$.

Through equations (11) and (12) $\Delta G_{\text {ads }}$ for an adsorption process is conventionally calculated.

$$
\Delta \mathrm{G}_{\mathrm{ads}}=-2.303 \mathrm{RT} \log (55.5 \mathrm{k})
$$

where 


$$
\mathrm{K}=\frac{\theta}{(1-\theta) \mathrm{C}}
$$

$\mathrm{C}$ is the extract concentration and 55.5 is concentration of water expressed in moles (i.e. $\sim 1000 \mathrm{~g} / \mathrm{dm}^{3}$ ) [10, 23]. The values of $\Delta G_{\text {ads }}$ evaluated through the equation (11) are presented in Table 3.

The ideal Langmuir plot has been shown to have a slope of unity and intercept of zero [24, 25]. As can been seen the from Table 2, slopes obtained for the Langmuir plots are not far from unity, with intercepts close to zero, and good $\mathrm{R}^{2}$ values. Also, the values of $\Delta G_{\text {ads }}$ obtained through this isotherm are in good agreement with those evaluated through the conventional method as shown in Table 3. Therefore, these facts are indicative of suitability of the Langmuir isotherm model to the adsorption behaviour of this plant extract. Generally, Langmuir isotherm is applicable to both physisorption and chemisorption and a sign of monolayer.

Table 2. Parameters of the various Adsorption Isotherms for Adsorption of Leaf Extract of Securinega virosa onto the mild steel surface

\begin{tabular}{|c|c|c|c|c|c|c|}
\hline Isotherm & $\begin{array}{l}\text { Temp } \\
\text { (K) }\end{array}$ & $\mathbf{R}^{2}$ & Slope & Intercept & $\mathrm{K}_{\mathrm{ads}}$ & $\begin{array}{c}\Delta G_{a d s} \\
(\mathrm{~kJ} / \mathrm{mol})\end{array}$ \\
\hline
\end{tabular}

Langmuir

\begin{tabular}{rcccccc} 
Flory-Huggins & \multicolumn{3}{c}{$\mathrm{x}$} & & \multicolumn{3}{c}{$\alpha$} \\
301 & 0.9132 & 0.6725 & +0.5228 & 3.3327 & +0.7744 & -13.07 \\
305 & 0.9521 & 0.9813 & +0.7147 & 5.1844 & +1.1300 & -14.36 \\
309 & 0.8949 & 0.8276 & +0.6963 & 4.9694 & +0.9530 & -14.44 \\
313 & 0.9698 & 1.0803 & +0.8899 & 7.7607 & +1.2440 & -15.79
\end{tabular}

Adejo- Ekwenchi

b

$\begin{array}{lllllll}301 & 0.9946 & 0.5598 & 0.6802 & 4.7885 & 0.5598 & -13.97 \\ 305 & 0.9532 & 0.5583 & 0.7225 & 5.2784 & 0.5583 & -14.41 \\ 309 & 0.9269 & 0.5676 & 0.7598 & 5.7517 & 0.5676 & -14.82 \\ 313 & 0.9699 & 0.5765 & 0.8062 & 6.4003 & 0.5765 & -15.29\end{array}$




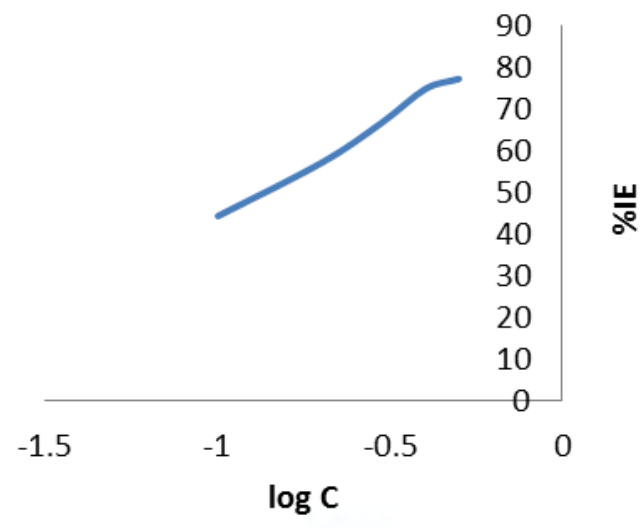

Figure 1. Relationship between Inhibition Efficiency and logarithm of Concentration at $315 \mathrm{~K}$ for the Extract of Securinega virosa

The parameter $\mathrm{n}$ of the Freundlich isotherm relates to the adsorption intensity, and it varies with the heterogeneity of the material [26] and it has been shown to have a typical value is 0.6 [20]. With the exception of its the value at $301 \mathrm{~K}$ no other value is close to the typical value (Table 2). Also, the values of $\Delta G_{a d s}$ obtained through this isotherm model are not in good agreement with those calculated through the conventional method. Therefore, this adsorption process cannot, reasonably, be modelled by the Freundlich isotherm, in spite of the seemly good values of $R^{2}$.

The Temkin isotherm has been shown to be a feature of chemisorption and monolayer [27] and also indication of interaction of uncharged molecules on a heterogeneous surface [28]. The negative values of parameter $\alpha$, therefore, show existence of repulsive interaction among the molecules in the adsorbed layer. This might have accounted for the non-unity and non-zero of the slope and intercept, respectively, of the Langmuir plots. The values of $\mathrm{R}^{2}$ for this isotherm are good, with comparable $\Delta G_{\text {ads }}$ values, although there are below values ascribed for chemisorption, this adsorption can be modelled by Temkin isotherm.

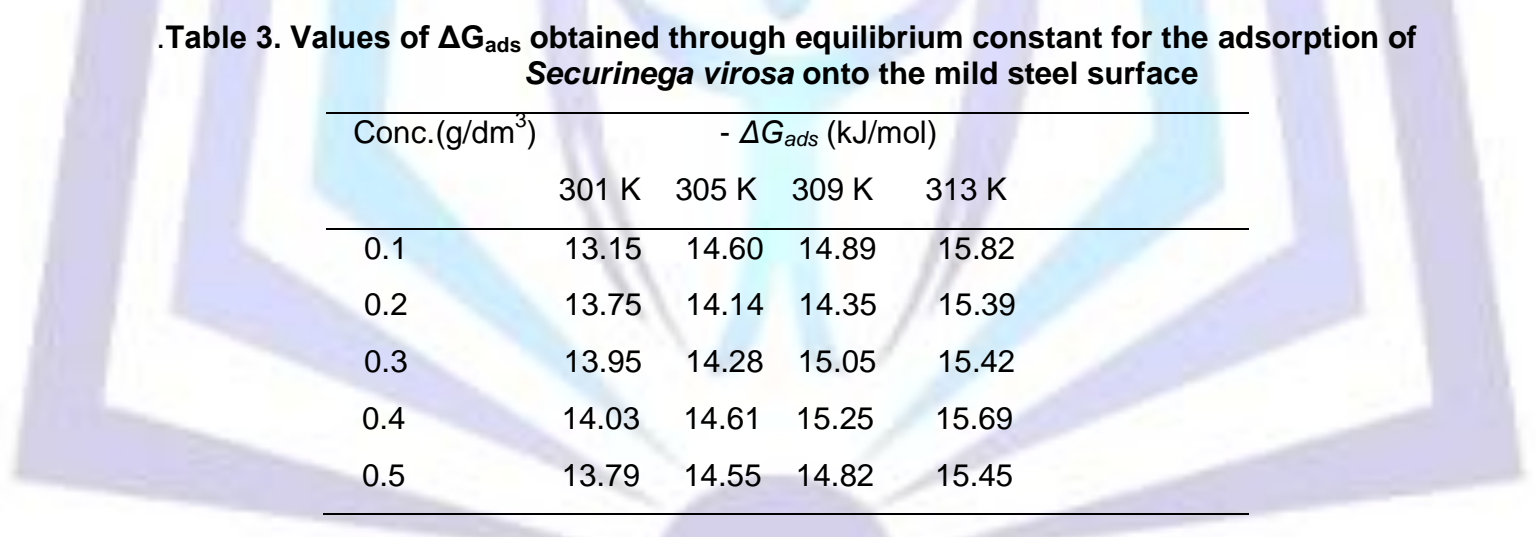

The parameter, $x$, of Flory-Huggins isotherm indicates the number of active sites occupied by one inhibitor molecule or number of water molecules replace by one molecule of the adsorbate. Value of $x>1$ implies that one inhibitor molecule replaces more than one water molecule on the adsorbent surface [29]. The values of $x$ (Table 2) obtained are less than one except at $315 \mathrm{~K}$, meaning more than one molecules of the inhibitor occupied one active site during the inhibition process, except at $315 \mathrm{~K}$. The facts that $x$ values are not clearly defined for this extract means that the data do not properly fit into this isotherm model.

The Adejo-Ekwenchi isotherm is centred on the fact that for an adsorption process, the amount of adsorbate uptake from bulk concentration has inverse relationship with the difference between the total available surface on the adsorbent surface and the fraction that is covered by the adsorbate at a given temperature, prior to the attainment of maximum value of surface coverage [11]. Decrease in the value of $b$ of the isotherm with rise in temperature signifies physisorption, while increase or fairly constant value indicates chemisorption [10,11,30]. From Table 2 it is obvious that the adsorption of this plant extract onto the metal surface is unambiguously chemisorption as $b$ fairly increases with rise in temperature. Supportively, the values of $\Delta \mathrm{G}_{\mathrm{ads}}$ obtained through this isotherm are close to those of Langmuir isotherm and the conventional method. 


\section{CONCLUSION}

The methanol extract of $S$. virosa as an inhibitor for the corrosion of mild steel in $2 \mathrm{M} \mathrm{HCl}$ best fitted into Langmuir, Temkin, and Adejo-Ekwenchi isotherm models and is chemisorption. This conforms to the fact that adsorption of organic substances onto metal surfaces is described most frequently by Langmuir, Temkin or Frumkin [9].

\section{REFERENCES}

[1] S. Sohn, D. Kim, Chemosphere, 58(2005) 115 - 123

[2] T. Graf, C. Pasel, M. Luckas, Adsorption, 18 (2012) 127-141

[3] Y. Foo, B. H. Hameed, Chem. Engineering J.156 (2010) 2- 10.

[4] A. W. Adamson, A. P. Gast, Physical Chemistry of Surfaces, $6^{\text {th }}$ ed. John Wiley and Sons Inc., USA, 1997

[5] Y. S. Ho, J. F. Porter, G. McKay, Water, Air and Soil Pollution, 141(2002) 1-33

[6] H. Radnia, A. A. Ghoreyshi, H. Younesi, Iranian J. Energy and Environ., 2 (2011) 250-257

[7] L. A. Nnanna, V. U. Obasi, O. C. Nwadiuko, K. I. Mejeh, N. D. Ekekwe, S. C. Udensi, Archives of App. Sci. Res., 4(2011) 207-217

[8] S. O. Adejo, M. M. Ekwenchi, F. Momoh, E. Odiniya, Inter. J. Modern Chemistry, 1(2012) 125-134

[9] A. Popova, M. Christov, A. Vasilev, A. Zwetanova, Corrosion Science, 53 (2011) 679-686

[10] S. O. Adejo, M. M. Ekwenchi, IOSR J. Appl. Chemistry, 6(2014) 66-71. doi 10.9790/5736-0656671

[11] S. O. Adejo, M. M. Ekwenchi, J. U. Ahile, J. A. Gbertyo, A. Kaior, J. Emerging Trends in Eng. Appl. Sci. (JETEAS), 5(2014) 201-205

[12] S. O. Adejo, J. A. Gbertyo, J. U. Ahile, Inter. J. Modern Chemistry, 4(2013) 137-146

[13] S. O. Adejo, S. G. Yiase, J. U. Ahile, T. G. Tyohemba, J. A. Gbertyo, Archives Appl. Sci. Res., 5(2013) 25-32

[14] K. Orubite-Okorosaye, N. C. Oforka, J. Appl. Sci. Environ. Mgt, 8 (2004) 57-61

[15] A. K. Maayta, The J. Corr. Sci. Eng., 3(2002)25-30

[16] D. Rani, S. Selvaraj, Archives Appl. Sci. Res., 2(2010a) 140-150

[17] A. A. Siaka, N. O. Eddy, S. O. Idris, A. Muhammad, C. M. Elinge, F. A. Atiku, Innovations Sci. Eng., 2(2012) 41-48

[18] S. O. Adejo, J. A. Gbertyo, J. U. Ahile, T. G. Tyohemba, Inter. J. Sci. Eng. Res., 4(2013) 2308-2313

[19] E. I. Ating, S. A. Umoren, I. I. Udousoro, E. E. Ebenso, A. P. Udoh, Green Chem. Lett. Rev., 3(2010) 61-68

[20] A. A. Khadom, A. S. Yaro, A. H. Abdul, J. Chilean Chem. Soc., 55(2010) 150-152

[21] Z. Benmaamar, A. Bengueddach, J. Appl. Sci. Environ. Sanitation, 2(2007) 43-56

[22] O. K. Abiola, J. Chilean Chem. Soc., 50 (2005) 685-690

[23] D. M. Bastidas, P. P. Gomez, E. Cano, Revista Metallurgy, 41(2005) 98-106

[24] I. M. Mejeha, A. A. Uroh, K. B. Okeoma, G. A. Alozie, Afri. J. Pure Appl. Chemistry, 4 (2010) 158-165

[25] C. O. Akalezi, C. K. Enenebaku, C. E. Ogukwe, E. E. Oguzie, J. Chem. Soc. Nigeria, 37(2012) 117-124

[26] S. Chatterjee, D. S. Lee, M. W. Lee, S. H. Woo, Bioresource Techn., 100 (2009) 2803-2809

[27] ch.ntu.edu.tw. http://www.ch.ntu.edu cymou/catalyst94/0922 C: retrieved 29/04/2014

[28] S. A. Umoren, I. B. Obot, I. O. Igwe, The Open Corr. J., 2 (2009) 1-5

[29] R. Saratha, S. V. Priya, P. Thilagavathy, E-J. Chemistry, 6(2009) 785-795

[30] S. O. Adejo, M. M. Ekwenchi, P. O. Olatunde, F. Agbajeola, IOSR J. Appl. Chemistry, 7(2014) 55-60 